medRxiv preprint doi: https://doi.org/10.1101/2021.12.24.21268382; this version posted January 2, 2022. The copyright holder for this preprint (which was not certified by peer review) is the author/funder, who has granted medRxiv a license to display the preprint in perpetuity.

It is made available under a CC-BY 4.0 International license .

\title{
Early estimates of SARS-CoV-2 Omicron variant severity based on a matched cohort study, Ontario, Canada
}

Ana Cecilia Ulloa, MPH, Sarah A. Buchan, PhD, Nick Daneman, MD MSc, Kevin A Brown, PhD

\author{
Affiliations \\ Public Health Ontario, Toronto, Canada (Ulloa, Buchan, Daneman, Brown)
}

Version dates

V1-Original version - December 24, 2021

V2-Update 1 (this version) - January 2, 2022

\begin{abstract}
While it is now evident that Omicron is rapidly replacing Delta, largely due to immune escape, it is less clear how the severity of Omicron compares to Delta. In Ontario, we sought to examine hospitalization and death associated with Omicron, as compared to cases infected with Delta. We conducted a matched cohort study, considering time to hospitalization or death as the outcome. Cases were matched on gender, age, vaccination status, health region and onset date. We identified 29,594 Omicron cases that met eligibility criteria, of which 11,622 could be matched with at least one Delta case $(\mathrm{N}=14,181)$. There were 59 (0.51\%) hospitalizations and $3(0.03 \%)$ deaths among matched Omicron cases, compared to 221 (1.6\%) hospitalizations and 17 (0.12\%) deaths among matched Delta cases. The risk of hospitalization or death was $65 \%$ lower (hazard ratio, $\mathrm{HR}=0.35,95 \% \mathrm{Cl}: 0.26,0.46$ ) among Omicron cases compared to Delta cases, while risk of intensive care unit admission or death was $83 \%$ lower $(\mathrm{HR}=0.17,95 \% \mathrm{Cl}: 0.08,0.37)$. While severity is likely to be reduced, the absolute number of hospitalizations and impact on the healthcare system may nevertheless be significant due to the increased transmissibility of Omicron.
\end{abstract}

\section{Introduction}

The WHO designated Omicron as a Variant of Concern on November 26, 2021. ${ }^{1}$ Omicron has more than 30 mutations in the spike protein, and it is now evident that Omicron is rapidly replacing Delta ${ }^{2}$ due to increased levels of immune escape. It is less clear how the severity of Omicron compares to Delta. Early data from South Africa suggests that Omicron may be less severe; ${ }^{3}$ however, the low average age, extent of previous infection, and low vaccination rates impact generalizability to other countries. In Ontario, we sought to 
medRxiv preprint doi: https://doi.org/10.1101/2021.12.24.21268382; this version posted January 2, 2022. The copyright holder for this preprint (which was not certified by peer review) is the author/funder, who has granted medRxiv a license to display the preprint in perpetuity.

It is made available under a CC-BY 4.0 International license .

examine rates of hospitalization, intensive care unit admission, and death associated with Omicron, as compared to matched patients infected with Delta.

\section{Methods}

We conducted a retrospective population-wide matched cohort study of patients infected with Omicron and Delta variants, using Ontario's Public Health Case and Contact Management Solution (CCM), a database containing all diagnosed SARS-CoV-2 infections, linked to Ontario Ministry of Health's COVaxON application, containing all COVID-19 vaccination records in the province. Cases were included if onset occurred between November 22 (first Omicron case in Ontario) and December 25, 2021. Case onset date was defined by symptom onset, or for asymptomatic cases, specimen collection. Cases were excluded if they were missing onset date, age, gender, or were hospital-acquired. Omicron cases included those identified by whole genome sequencing (WGS), S-gene target failure (SGTF) with cycle threshold $\leq 30$ before December 13 (date of 50\% Omicron prevalence), ${ }^{2}$ and any SGTF on or after December 13. Delta cases included those detected by WGS, those with amplification of the S-gene, and all cases not identified as Omicron prior to December 3 (date of $5 \%$ Omicron prevalence). ${ }^{2}$ Omicron cases were matched to Delta cases using up to 2:1 matching on gender (male, female, other), age (0-4, 5-11, 12-18, 19-29, 30-39, 40-49, 50-59, 60-69, 70-79, 80+), vaccination status (0 doses, 1 dose, 2 doses, 3 doses), time since most recent dose ( $>7$ or 14 days to $<3$ months, 3-6 months, $>6$ months), region and onset date ( \pm 7 days). Cox proportional hazards models accounting for clustering within matched sets were used to determine the hazards of hospitalization or death, and intensive care unit (ICU) admission, compared to Delta cases. Due to concerns around incidental SARS-CoV-2 findings upon hospital admission due to universal screening practices in hospitals, we conducted a separate sensitivity analysis excluding cases with first positive specimen collection on the day of or the day prior to hospitalization. Stratified hazards were estimated by gender, age group, and vaccination status.

\section{Results}

We identified 29,594 Omicron cases that met eligibility criteria, of which 11,622 were matched with $\geq 1$ Delta case $(\mathrm{N}=14,181$, Table 1$)$. There were $59(0.51 \%)$ hospitalizations and $3(0.03 \%)$ deaths among matched Omicron cases, compared to $221(1.56 \%)$ hospitalizations 
medRxiv preprint doi: https://doi.org/10.1101/2021.12.24.21268382; this version posted January 2, 2022. The copyright holder for this preprint (which was not certified by peer review) is the author/funder, who has granted medRxiv a license to display the preprint in perpetuity.

It is made available under a CC-BY 4.0 International license .

and $17(0.12 \%)$ deaths among matched Delta cases. The risk of hospitalization or death was $65 \%$ lower (hazard ratio, $\mathrm{HR}=0.35,95 \% \mathrm{Cl}: 0.26,0.46$, Table 2 ) in Omicron compared to Delta cases (Figure 1), and the risk of ICU admission or death was $83 \%$ lower ( $\mathrm{HR}=0.17,95 \% \mathrm{Cl}$ :

$0.08,0.37)$. A sensitivity analysis excluding cases with potential incidental SARS-CoV-2 findings on hospital admission, also demonstrated reduced severity of Omicron relative to Delta ( $\mathrm{HR}=0.25,95 \% \mathrm{Cl}: 0.16,0.41)$. Stratified estimates of Omicron severity by age, gender, and vaccination status all indicated reduced severity of Omicron (Table 2).

\section{Discussion}

In this matched study of over 11,000 Omicron cases in Ontario, Canada, we found that the risk of hospitalization was $65 \%$ lower for SARS-CoV-2 cases infected with the Omicron variant relative to the Delta variant. Our results align with findings from South Africa, Scotland and England, all of which have demonstrated substantial decreases in risk of hospitalization associated with Omicron. ${ }^{3-5}$ One early hypothesis for increased transmissibility with decreased severity is the increased replication in the bronchi but decreased replication in lung parenchyma. ${ }^{6}$

Our study has some limitations, in particular the short follow-up duration and potential misclassification due to incidental findings from hospital admission screening, and incomplete public health follow-up as incidence increased. Nevertheless, Omicron appears to demonstrate lower disease severity for both vaccinated and unvaccinated individuals. While severity is likely to be reduced, the absolute number of hospitalizations and impact on the healthcare system is likely to be significant due to the large number of Omicron infections.

\section{References}

1. Callaway E. Heavily mutated Omicron variant puts scientists on alert. Nature. 2021;600(7887):21-21. doi:10.1038/d41586-021-03552-w

2. Early Dynamics of Omicron in Ontario, November 1 to December 16, 2021 Published: December 21, 2021. Public Health Ontario; 2021:5. Accessed December 24, 2021. https://www.publichealthontario.ca/-/media/documents/ncov/epi/covid-19-earlydynamics-omicron-ontario-epi-summary.pdf 
medRxiv preprint doi: https://doi.org/10.1101/2021.12.24.21268382; this version posted January 2, 2022. The copyright holder for this preprint (which was not certified by peer review) is the author/funder, who has granted medRxiv a license to display the preprint in perpetuity.

It is made available under a CC-BY 4.0 International license.

3. Wolter N, Jassat W, Walaza S, et al. Early Assessment of the Clinical Severity of the SARSCoV-2 Omicron Variant in South Africa. Infectious Diseases (except HIV/AIDS); 2021. doi:10.1101/2021.12.21.21268116

4. Ferguson N. Report 50: Effectiveness of SARS-CoV-2 Vaccines in England in 2021: A Whole Population Survival Analysis. Imperial College London; 2021. doi:10.25561/93035

5. Sheikh A, Kerr S, Woolhouse M, McMenamin J, Robertson C. Severity of Omicron Variant of Concern and Vaccine Effectiveness against Symptomatic Disease: National Cohort with Nested Test Negative Design Study in Scotland.; 2021.

6. HKUMed finds Omicron SARS-CoV-2 can infect faster and better than Delta in human bronchus but with less severe infection in lung. Accessed December 24, 2021. https://www.med.hku.hk/en/news/press/20211215-omicron-sars-cov-2-infection

Figures and Tables

Table 1. Demographic characteristics, vaccination status, and outcomes among SARS-CoV-2 Delta and Omicron variant cases, and among matched cases ( $N, \%)$.

\begin{tabular}{|c|c|c|c|c|}
\hline & \multicolumn{2}{|c|}{ Full Cohort } & \multicolumn{2}{|c|}{ Matched Cohort } \\
\hline & Delta & Omicron & Delta & Omicron \\
\hline & $\mathrm{N}=22,769$ & $\mathrm{~N}=29,594$ & $\mathrm{~N}=14,181$ & $\mathrm{~N}=11,622$ \\
\hline Age (median, [IQR]) & $33.0[12.0,49.0]$ & $30.0[21.0,44.0]$ & $31.0[14.0,46.0]$ & $31.0[16.0,46.0]$ \\
\hline \multicolumn{5}{|l|}{ Gender } \\
\hline Female & $11,198(49.2)$ & $14,779(49.9)$ & $7,062(49.8)$ & $5,783(49.8)$ \\
\hline Male & $11,513(50.6)$ & $14,783(50.0)$ & $7,107(50.1)$ & $5,831(50.2)$ \\
\hline Other & $58(0.3)$ & $32(0.1)$ & $12(0.1)$ & $8(0.1)$ \\
\hline \multicolumn{5}{|c|}{$\begin{array}{l}\text { Vaccination status (doses, } \\
\text { and time since last dose) }\end{array}$} \\
\hline 0 doses & $10,286(45.2)$ & 4,005 (13.5) & $5,108(36.0)$ & $3,629(31.2)$ \\
\hline \multicolumn{5}{|l|}{1 dose } \\
\hline$>14 \mathrm{~d}$ to $<3$ months & $1037(4.6)$ & $1,155(3.9)$ & $827(5.8)$ & $724(6.2)$ \\
\hline 3 to 6 months & $139(0.6)$ & $87(0.3)$ & $59(0.4)$ & $46(0.4)$ \\
\hline$>6$ months & $133(0.6)$ & $102(0.3)$ & $46(0.3)$ & $39(0.3)$ \\
\hline \multicolumn{5}{|l|}{2 doses } \\
\hline$>7 \mathrm{~d}$ to $<3$ months & $616(2.7)$ & $1,025(3.5)$ & $381(2.7)$ & $320(2.8)$ \\
\hline 3 to 6 months & $5,442(23.9)$ & $12,958(43.8)$ & $4,166(29.4)$ & $3,719(32.0)$ \\
\hline$>6$ months & $4,348(19.1)$ & $8,469(28.6)$ & $3,125(22.0)$ & $2,731(23.5)$ \\
\hline \multicolumn{5}{|l|}{3 doses } \\
\hline$>7 \mathrm{~d}$ to $<3$ months & $721(3.2)$ & $1,710(5.8)$ & $450(3.2)$ & $396(3.4)$ \\
\hline 3 to 6 months & $47(0.2)$ & $83(0.3)$ & $19(0.1)$ & $18(0.2)$ \\
\hline \multicolumn{5}{|l|}{ Outcomes } \\
\hline Hospitalization/death & $601(2.64)$ & $75(0.25)$ & $221(1.56)$ & $59(0.51)$ \\
\hline ICU admission/death & $190(0.83)$ & $8(0.03)$ & $60(0.42)$ & $7(0.06)$ \\
\hline Deaths & $83(0.36)$ & $3(0.01)$ & $17(0.12)$ & $3(0.03)$ \\
\hline
\end{tabular}

Note: $d$, days; IQR, inter-quartile range; ICU, intensive care unit 
medRxiv preprint doi: https://doi.org/10.1101/2021.12.24.21268382; this version posted January 2, 2022. The copyright holder for this preprint (which was not certified by peer review) is the author/funder, who has granted medRxiv a license to display the preprint in perpetuity.

It is made available under a CC-BY 4.0 International license.

Table 2: Risk of hospitalization, intensive care unit admission, and death associated with Omicron cases relative to matched Delta cases, Ontario, Canada. All analyses are based on proportional hazards models and presented as hazards ratios for Omicron relative to Delta. Hazards ratios of 1 indicate equal risk for Omicron relative to Delta, $<1$ indicate reduced severity of Omicron, $>1$ indicate increased severity of Omicron.

\begin{tabular}{|l|c|c|c|c|c|}
\hline & $\begin{array}{c}\text { Delta } \\
\text { cases } \\
\mathrm{N}(\%)\end{array}$ & $\begin{array}{c}\text { Omicron } \\
\text { cases } \\
\mathrm{N}(\%)\end{array}$ & $\begin{array}{c}\text { Hospitalization } \\
\text { or death, } \\
\text { HR }(95 \% \mathrm{Cl})\end{array}$ & $\begin{array}{c}\text { ICU admission } \\
\text { or death, } \\
\text { HR }(95 \% \mathrm{Cl})\end{array}$ & $\begin{array}{c}\text { Hospitalization } \\
\text { or death SA*, } \\
\text { HR }(95 \% \mathrm{Cl})\end{array}$ \\
\hline Total & $14,181(100)$ & $11,622(100)$ & $0.35(0.26,0.46)$ & $0.17(0.08,0.37)$ & $0.25(0.16,0.41)$ \\
\hline Stratified analyses & & & & & \\
\hline Gender & & & & & \\
\hline Female & $7,062(49.8)$ & $5,783(49.8)$ & $0.36(0.25,0.54)$ & $0.24(0.08,0.68)$ & $0.29(0.15,0.54)$ \\
\hline Male & $7,107(50.1)$ & $5,831(50.2)$ & $0.33(0.23,0.49)$ & $0.12(0.04,0.39)$ & $0.22(0.10,0.46)$ \\
\hline Age & & & & & \\
\hline$<60$ & $12,754(89.9)$ & $10,482(90.2)$ & $0.30(0.19,0.48)$ & $0.05(0.01,0.38)$ & $0.30(0.14,0.63)$ \\
\hline$\geq 60$ & $1,427(10.1)$ & $1,140(9.8)$ & $0.40(0.28,0.56)$ & $0.28(0.11,0.67)$ & $0.24(0.13,0.46)$ \\
\hline Vaccine doses & & & & & \\
\hline 0 doses & $5,108(36.0)$ & $3,629(31.2)$ & $0.40(0.28,0.56)$ & $0.16(0.05,0.50)$ & $0.17(0.06,0.46)$ \\
\hline 2 doses & $7,672(54.1)$ & $6,770(58.3)$ & $0.40(0.27,0.58)$ & $0.12(0.03,0.51)$ & $0.25(0.13,0.50)$ \\
\hline
\end{tabular}

$\mathrm{Cl}=$ confidence interval; $\mathrm{HR}=$ hazard ratio; ICU=intensive care unit; *sensitivity analysis excludes Delta or Omicron cases with potential incidental SARS-CoV-2 findings (first positive specimen collection on the day of or the day prior to hospitalization)

Figure 1. SARS-CoV-2 associated hospitalization or death among matched Omicron variant $(\mathrm{N}=11,622$, orange line) and Delta variant cases $(\mathrm{N}=14,181$, green line) cases as a function of days since onset. Date of onset was defined as symptom onset date, falling back to first positive specimen collection date in the absence of a documented symptom onset date.

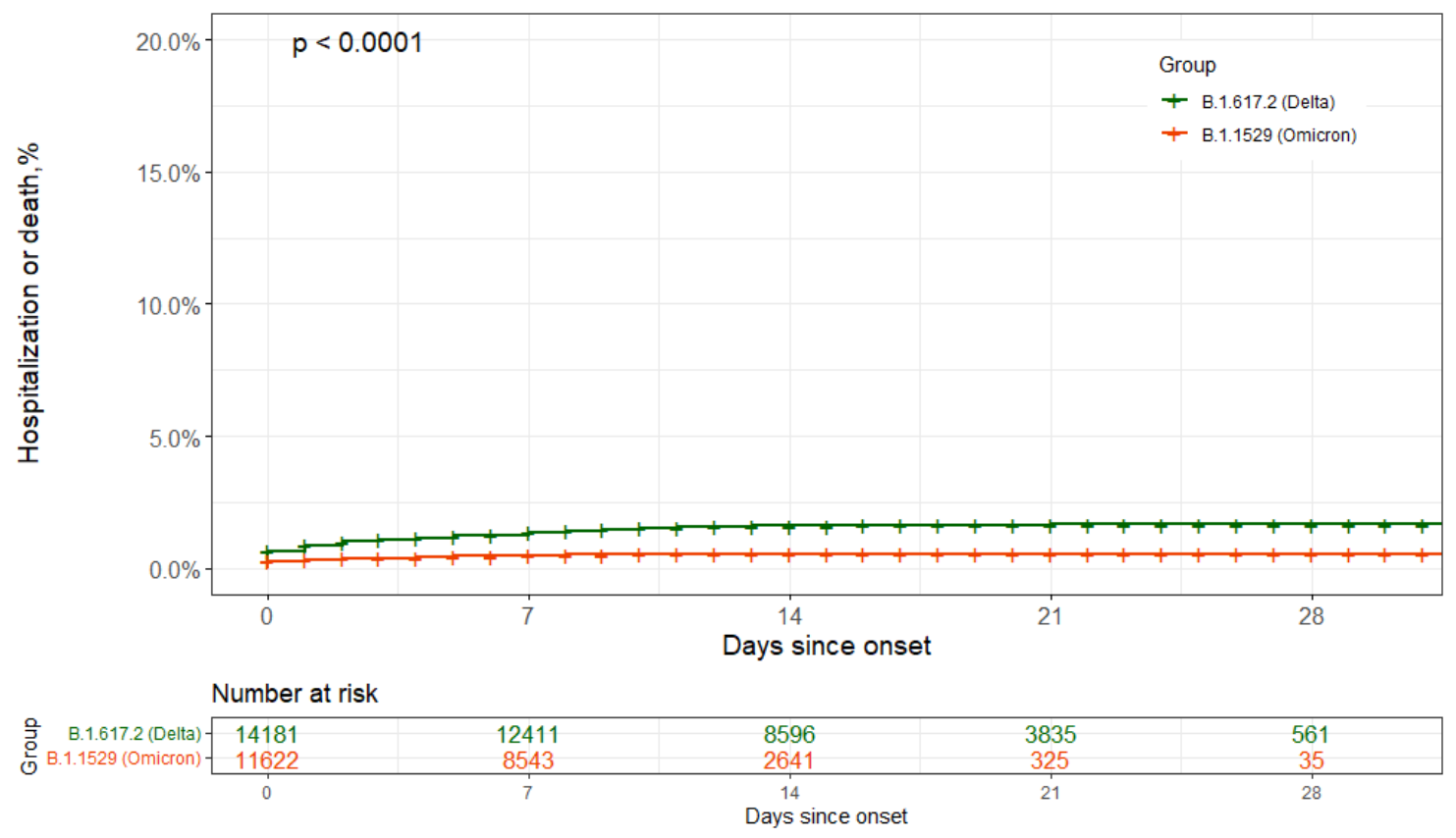

